Relations industrielles

Industrial Relations

\title{
Labour Markets, Flexible Specialization and the New Microcorporatism The Case of Canada's Major Appliance Industry
}

Marchés du travail, spécialisation flexible et nouveau microcorporatisme : le cas de l'industrie des appareils ménagers au Canada

\section{Mercado de trabajo, especialización flexible y neo-corporatismo : el caso de la industria canadiense de electro-domesticos}

\section{Don Wells}

Volume 56, numéro 2, printemps 2001

Syndicats et restructuration des milieux de travail Local unions and workplace restructuring

URI : https://id.erudit.org/iderudit/000026ar

DOI : https://doi.org/10.7202/000026ar

Aller au sommaire du numéro

Éditeur(s)

Département des relations industrielles de l’Université Laval

ISSN

0034-379X (imprimé)

1703-8138 (numérique)

Découvrir la revue

Citer cet article

Wells, D. (2001). Labour Markets, Flexible Specialization and the New Microcorporatism The Case of Canada's Major Appliance Industry. Relations industrielles / Industrial Relations, 56(2), 279-306.

https://doi.org/10.7202/000026ar
Résumé de l'article

Dans le contexte particulier des organisations syndiquées, les change- ments apportés au processus de production et associés à la haute performance ainsi qu'aux systèmes de gestion participatifs ont le potentiel de créer des relations industrielles microcorporatistes apparentées à celles qui étaient en vigueur au début du $20^{\mathrm{e}}$ siècle au Canada, aux États-Unis et ailleurs. Ce microcorporatisme se manifeste notamment dans le syndicalisme japonais d'entreprise. Dans la mesure où ce potentiel est réalisé, ces formes de microcorporatisme pourtant en marge des systèmes de relations industrielles canadiens dans le passé, deviennent beaucoup plus centrales. Les changements de structures du marché du travail contribuent particulièrement à changer le système de relations industrielles. En effet, la reconfiguration des marchés interne et externe du travail autour de formes contingentes de travail augmente la dépendance des travailleurs pour des employeurs et des lieux de travail particuliers. Cette dépendance est de plus conditionnée par l'accroissement de la compétitivité inter et intra-entreprise. Au Canada, particulièrement dans le secteur manufacturier, ces formes de compétitivité se sont accrues suite à l'entrée en vigueur l'Accord de libre-échange entre le Canada et les États-Unis (ALE) et de l'Accord de libre-échange nord-américain (ALENA). Face à de nouvelles pressions concurrentielles et de nouvelles technologies de production, plusieurs dirigeants d'entreprises ont saisi l'occasion de promouvoir ces nouvelles tendances microcorporatistes. Par exemple, dans les organisations qui introduisent de nouvelles technologies de production et qui poursuivent des objectifs de qualité, de flexibilité et de productivité, des stratégies de développement et de maintien du noyau de main-d'oeuvre qui coopère davantage dans le processus de restructuration des lieux de travail sont mises en oeuvre.

Ces liens entre les marchés du travail restratifiés, l'augmentation des pressions concurrentielles et les nouveaux processus de production, d'une part, et les nouvelles tendances microcorporatistes d'autre part, sont illustrés dans une étude de cas d'une usine de production d'appareils électro- ménagers qui a dû faire face à une rationalisation importante dans les dix dernières années. Cette rationalisation s'inscrit dans le cadre d'une restructuration continentale de l'industrie des appareils électroménagers au cours de laquelle des pertes d'emplois massives ont eu lieu ainsi que la disparition de la plupart des grandes entreprises de cette industrie au Canada. L'étude de cas suggère que les tendances microcorporatistes ne viennent pas de la construction d'une hégémonie profonde des valeurs managériales, ni du leadership syndical ou du noyau de main-d'oeuvre. Elles semblent davantage refléter les adaptations pragmatiques des travailleurs à leur vulnérabilité croissante au chômage et au sous-emploi causée par les nouvelles réalités compétitives.

Finalement, il faut aborder la question de l'impact potentiel des tendances microcorporatistes sur le système des relations industrielles et sur l'avenir politique du mouvement ouvrier. En fait, ces tendances ont des implications contradictoires et contingentes. Elles impliquent tout d'abord la mise en place d'un syndicalisme local plus fragmenté intériorisant davantage la logique de compétitivité du marché au profit de l'érosion du syndicalisme en tant que mouvement social et des politiques de travail social-démocrates. Puisque ces tendances vers le microcorporatisme sont contingentes à la fois des conditions externes et intérieurement contradictoires, le mouvement ouvrier et le système de relations industrielles peuvent prendre une toute autre direction. En effet, ils peuvent se tourner vers les nouvelles formes de résistance des travailleurs, en particulier celles qui se concentrent sur un meilleur contrôle ouvrier du processus de production
Tous droits réservés @ C Département des relations industrielles de l’Université Laval, 2001
Ce document est protégé par la loi sur le droit d'auteur. L’utilisation des services d’Érudit (y compris la reproduction) est assujettie à sa politique d'utilisation que vous pouvez consulter en ligne.

https://apropos.erudit.org/fr/usagers/politique-dutilisation/ 


\title{
Labour Markets, Flexible Specialization and the New Microcorporatism The Case of Canada's Major Appliance Industry
}

\author{
DON WeLlS
}

"High performance" management systems in unionized workplaces have the potential to create a more microcorporatist industrial relations system in Canada. Increasing interfirm and intrafirm competitiveness, combined with restratification of internal and external labour markets, promote a deepening of "core" workforce dependency on employers. Microcorporatist tendencies reflect more active worker cooperation in achieving management productivity, quality and flexibility goals. Analysis of development of these tendencies in the major appliance industry suggests that microcorporatism has contradictory implications. In one direction lies the displacement of both "social movement" unionism and social democratic labour politics by a local-centred unionism that is increasingly captured by the logic of market competition. In a second direction lies a logic of greater worker resistance related to increased worker control of labour processes.

- Wells, D., Labour Studies Programme and Political Science Department, McMaster University, Hamilton, Ontario.

- I am grateful to the Social Sciences and Humanities Research Council for funding this research as part of a larger project, with Norene Pupo and Jerry White, on union responses to economic restructuring in Canada. Thanks also to Jerry White, Norene Pupo, Ruth Frager, Jorge Garcia Orgales, Jim Stanford, and anonymous union members for information and advice; to Gary Beemer, John Adams, and Gillian Frost research assistance; to Celine Laporte and Anzele Charbonneau, Workplace Information Directorate of Human Resources Development Canada, for valuable data; and to Gregor Murray and anonymous reviewers for $R I / I R$ for perceptive criticisms and constructive suggestions.

- Material from interviews with eleven union leaders has been used in this article. Because the interviews often concerned politically sensitive issues, those interviewed were guaranteed anonymity. 


\section{TOWARD MICROCORPORATIST INDUSTRIAL RELATIONS?}

For some twenty years now, analysis has focused on flexible specialization and "high performance" management systems, ranging from an earlier emphasis on participatory "employee involvement" and "quality of work life" programs to current restructuring strategies that integrate employee participation into comprehensive systems of "continuous improvement" and "lean production." Often these innovations take place in non-union settings. Where unions have played roles in developing and negotiating these participatory management systems, those roles have been largely informal and at workplace level, and thus not very visible from the outside. Partly for this reason, many of these innovations have been seen as marginal to the industrial relations system, coexisting with it but not changing it substantially. Yet as these innovations become more pervasive, systematic and integral to overall labour processes, their transformative potential increases. In the context of ongoing changes in power relations between labour and capital at both micro and macropolitical levels, this article explores the links between these changes and the development of microcorporatist tendencies in parts of Canada's industrial relations system.

The argument is as follows. After defining microcorporatism's key features, the article situates the revival of microcorporatism in a context of contingent conducive factors. Included are dual external labour market structures that have carried over from Canada's Fordist "class compromise." Today's microcorporatist tendencies are built, it is argued, on the disciplining effects that expanding contingent, low wage, largely non-union "peripheral' labour markets have upon workers in declining "core" labour markets. Dependency of core workers on their particular employers is further enhanced by reductions in the social wage as state social programs have been cut back. An additional contingent factor is the increasing openness of much of Canada's economy to downward pressures on labour standards due to continental restructuring, especially following the implementation of the Canada-U.S. Free Trade Agreement and the North American Free Trade Agreement. Finally, in the context of heightened competition and technological changes in production processes, managerial restructuring is creating more functionally flexible core workforces (and more numerically flexible peripheral workforces) in internal labour markets. These themes are exemplified by the current restructuring of Canada's major appliance industry and by microcorporatist tendencies in a major appliance plant. The final section of the article examines the potential these tendencies have for the future of the industrial relations system and the politics of the labour movement in Canada. These tendencies contradict both social democratic labour politics and emerging "social movement" unionism. Instead, it is argued that the logic of microcorporatism leads to 
a more fragmented industrial relations system and a weaker, more employer-dominated labour movement. At the same time, it is also suggested that when contingent conducive factors supportive of microcorporatism are relaxed, another logic of worker resistance built around increased worker control over production also emerges.

\section{MICROCORPORATIST TENDENCIES IN CONTEMPORARY CONTEXT}

Although varied in application, microcorporatism has several defining characteristics.

- As opposed to coercive control of labour, microcorporatism entails, in large measure, persuasive management control systems, particularly for core workforces.

- In contrast to a greater focus on formal negotiation, microcorporatism centres on webs of informal labour-management relations.

- As a management control strategy, microcorporatism focuses on inducements such as corporate welfare benefits, enhanced job security, and other rewards for selected workers in the "corporate family."

- Through corporate consultation, communication and symbolic mechanisms, microcorporatism promotes a competitive enterprise culture among employees.

- Microcorporatism does not focus on the state or comprehensive interest organizations (e.g., central labour bodies, employer associations) but instead on individual enterprises and workplaces.

- Because of its firm-centred nature, microcorporatism is not a comprehensive (national or regional) industrial relations system.

- In contrast to class politics, microcorporatism signifies a fragmented, unitarist non-politics of worker-manager accommodation in labour processes.

Japanese enterprise unionism constitutes the best known contemporary prototype of unionized microcorporatism. In this model, core workers, most of whom still typically enjoy stable, long-term employment relations based on protected internal labour markets, engage in highly cooperative labour-management relations. ${ }^{1}$ Another prototype is the corporate welfare capitalism of the late $19^{\text {th }}$ and early $20^{\text {th }}$ centuries (Brandes 1976; Derber

1. This applies to core workers. Hybrids of this model are common outside Japan but do not embody all the microcorporatist features of the original (Kenney and Florida 1993; Graham 1993; Rinehart, Huxley and Robertson 1997; Babson 1995; Moody 1997). 
1970). Today welfare capitalism is manifested in company unions, employee representation plans, works councils, and certain models of employee ownership (Whyte and Whyte 1988). Although these forms of microcorporatism were antithetical to early Wagner model unionism, which required a greater degree of union autonomy from management, microcorporatist features have since penetrated modern industrial unionism (Jacoby and Verma 1992). In Canada and the U.S., welfare capitalist features tend to be found in larger, non-union firms, and often represent a continuation of the welfare capitalism found in such firms as General Electric, Westinghouse, General Motors, and other large, oligopolistic firms in the early $20^{\text {th }}$ century. ${ }^{2}$ Microcorporatist tendencies in the form of employee involvement programs and, more broadly, corporate "communitarian cultures" are also frequently seen in "independent local unions" (unaffiliated unions in single workplaces).

Contemporary tendencies toward microcorporatism imply a more fragmented industrial relations system, and further contraction of the Fordist core of unionized labour. As indicated above, microcorporatist tendencies are not simply discontinuous with the postwar industrial relations system; instead they are a continuation of some of its key characteristics, albeit in starker form. With the exception of rare pattern bargaining, Canada's postwar industrial relations system was built around a multitude of local collective agreements. Despite its name, the class compromise that gave birth to the postwar system was never a class compromise in any universal sense: it was a compromise between sections of capital, state elites and organized segments of the working class. Although, to some extent, union-negotiated wages, employment conditions, and "due process" spilled over from the unionized core to some non-union workplaces, much of Canada's working class was relegated to peripheral labour markets. Furthermore, although the postwar state increased the social wage, its redistributive capacity was weak. Because labour and its political allies failed to create a strong social democratic welfare state, Canadian workers remained more dependent on their employers than did workers in countries with stronger welfare states such as Germany or Austria, or in Scandinavia's social democratic regimes. This weakness at the level of the state reinforced the priority Canadian unions gave to winning "fringe benefits" for their members through collective bargaining at firm level. Labour's strength was further eroded by the role that union hierarchies above the local level played in substituting for, and demobilizing, workers collective power in the labour process (Wells 1995a, 1995b). In unionized workplaces, workers have been further divided

2. See Schatz (1983). However, earlier corporate paternalism did not include worker participation in production process decisions (Jacoby 1997). 
along age, skill, gender, ethnic and other lines, in particular through seniority provisions relevant to layoff, recall, job posting, training, benefits and other employment terms.

It is upon this legacy of a non-universal (union density never reached $40 \%$ ), decentralized industrial relations system, and weak welfare state that microcorporatist tendencies are now being built. Thus divided and weakened, unions have been unable to respond effectively to ongoing state and employer offensives of the past twenty years or so. Instead, labour has engaged in a fragmented politics of production that is increasingly dependent on the competitive fortunes of particular employers. This fragmentation is being further accelerated by the decline of big-factory capitalism and by forms of corporate restructuring in which individual plants are being left to "sink or swim" on their own.

Further reinforcing employee dependence on employers has been the "permeability" of Canadian Fordism to external trade and investment pressures (Jenson 1990) — a permeability that has markedly increased under the Canada-U.S. Free Trade Agreement (FTA) and the North American Free Trade Agreement (NAFTA). As a high labour standard region of North America, Canada is constrained by continental whipsawing pressures that reinforce economic insecurity and thus employee dependence. Moreover, ongoing erosion of the social wage induces a marriage of convenience between unions and aspects of welfare capitalism. Employers and unions both bargain for corporate welfare to bolster worker loyalty to their respective organizations, ${ }^{3}$ thus reinforcing the "dual loyalty" many workers have to their employer and union (Purcell 1960). Because they exclude much of the non-organized working class, private corporate welfare programs help not only to discipline labour but to restratify the working class.

Finally, microcorporatist tendencies are being reinforced by changes in external labour markets. A major cause has been deindustrialization and the rise of the private service sector with its large numbers of "bad" jobs. The trend toward an "hour glass labour market" with a growing peripheral labour market of short-term, part-time, low-paid jobs has reinforced the segmentation of external labour markets and the dependence of more fortunate core workers on their "standard" jobs (Jackson 1996; Picot and Heisz 2000; Burke and Shields 1999; Betcherman and Lowe 1997). Worker dependence in this context is especially strong in unionized workplaces where typical median age is now often in the mid forties to fifties. This reconfiguration of labour markets has been reinforced by public policies

3. Corporate welfare is becoming increasingly extensive, going beyond pensions, supplemental health benefits and dental benefits to legal aid plans, sabbaticals, educational assistance plans, etc. 
that discipline labour (e.g., higher unemployment, weaker employment insurance, lower welfare provisions, etc.) (McBride 1992). In addition, the disciplinary impact of major recessions in the 1980s and 1990s has carried over into economic growth phases characterized by increasing numbers of low-paid, insecure jobs.

In this context, managerial restructuring strategies have strengthened the organizational supports for microcorporatism. Not only are "bad" contingent jobs becoming an increasing proportion of external labour markets but, as well, they are becoming an increasing proportion of internal labour markets as managers develop core-periphery workforces within organizations. At the same time that managers augment peripheral workforces in external labour markets through outsourcing (subcontracting), and in internal labour markets through creating low cost, non-standard (e.g., part time, casual) job structures, managers are also creating new layers of core labour in their organizations. Core-periphery internal labour markets allow managers to pursue both a more coercive relation with peripheral workers and a more participative or cooperative strategy with core workers. Peripheral workers are a prime source of numerical flexibility since they are more readily hired and laid off, whereas core workers serve as sources of functionally flexible "multi-task" employees.

According to recent surveys, it is especially in establishments where competitiveness depends on product and service differentiation, and on technological innovation, that employers are adopting "high performance" models based on employee participation (e.g., teams, labour-management committees, problem-solving groups, training) and/or incentive pay systems (e.g., gain-sharing, profit-sharing, pay-for-knowledge) (Betcherman 1999: 27-31). ${ }^{4}$ Another recent survey of restructuring in Canada concludes that two related management strategies, namely downsizing (including the discard of non-core corporate competencies) and "re-engineering" (including redesign of cross-departmental functions, devolution of decisions to lower level management, flattening managerial hierarchies) are often associated with such innovations as team-building, "just-in-time" production, and continuous improvement in production efficiency. Along with labour process restructuring associated with the introduction of new technologies, including computerized production, robotics and numericallycontrolled machines, these innovations imply more responsibilities for workers (Magun 1998: 11,18, 21). These findings are consistent with a

4. This is based on findings from two surveys: (1) a 1993 survey of 714 Canadian establishments in four sectors: wood products, fabricated metal products, electrical and electronic products and business services; (2) a 1995 survey of 2,584 Canadian establishments in all sectors except agriculture and government (Betcherman 1999: 27-31). 
range of case studies that suggest a convergence of new human resource practices around "differentiation-based" business strategies focused on product innovation and quality; a more strategic role for human resource management and industrial relations driven by technological changes and reorganized (often decentralized) work processes; efficiency-oriented (lean) production; emphasis on both technical and cultural skills training; complex, on-going labour relations beyond contract bargaining and enforcement; and the negotiation of greater production flexibility in return for increased job security (Betcherman 1999: 37).

More cooperative functions are also increasingly seen in local unionmanagement relations (Wells 1997a). Reviewing firm-level studies of the impact of restructuring on employment relations, Verma and Chaykowski see a discernible movement "albeit slowly and cautiously, towards greater cooperation, participation and joint decision-making in a variety of forums and areas" of union-management relations (1999: 346).

Finally, because of the implicitly coercive nature of internal and external labour market polarization, managers do not need to engender a "deep hegemony" akin to William F. Whyte's pathologically conformist "organization man" (1957), or to the "nascent totalitarianism" that Willmott (1993) sees in the new "corporate culturalism." Indeed, there is little evidence that this kind of corporate restructuring succeeds in (or requires) a significant degree of internalization of managerial values among production workers (Wells 1996, 1997a) Nor is there evidence of corporate "feudalist" control of workers' lives against which Arthur Ross (1958) warned. Rather, in this labour market context, microcorporatist tendencies are more consistent with workers' pragmatic accommodation based on job fear (Wells 1996).

The primary empirical focus of this article is a case study of these cooperativist and participatory tendencies and their microcorporatist implications in a large major appliance plant. Because case studies have inherently limited generalizability and because local unions and workplaces are always grounded in particular histories, this study makes no conclusive claims about the extent of microcorporatist tendencies. Instead, it attempts to situate these tendencies in relevant contexts and to explore their potential impact on the industrial relations system and, in particular, their potential impact on organized labour.

\section{JOB INSECURITY AND RESTRUCTURING IN THE MAJOR APPLIANCE INDUSTRY}

To understand the explanatory links between labour markets, corporate restructuring and microcorporatist tendencies in the workplace, it is 
useful to understand first how these forces have developed at the level of the major appliance industry as a whole. A key subsector of the electrical and electronics sector, the major appliance industry produces a wide range of "white goods," including stoves and ranges, dishwashers, freezers, refrigerators, clothes dryers and washing machines. Until recently, Canada's appliance industry centred on domestic consumer markets, but during the 1990s the proportion of appliances produced for export has risen from 11\% to about $60 \%$. At the same time, the value of imports in the industry now exceeds exports by almost four to one (Industry Canada 2000: chap. 5). While U.S. firms are the main competitors in Canadian markets, imports from Japan, Mexico and other countries have been growing rapidly. In this environment, the major appliance industry has become increasingly vulnerable and new capital investments are below previous levels (Industry Canada 2000: chap. 4). Although the value of production per employee rose over $40 \%$ in the last decade in Canada, U.S. labour productivity rose over $90 \%$ in the same period. U.S. labour productivity in the industry is now 2.5 times higher than Canada's (Industry Canada 2000: chap. 2).

Continentalization of production, especially following the Canada-U.S. Free Trade Agreement (FTA) in 1989 and the North American Free Trade Agreement in 1994, has been the major cause of this new vulnerability. Prior to the FTA, the industry was protected by tariffs ranging from 9.2 to $14.1 \%,{ }^{5}$ and by nationally specific production standards (Camco 2000c: 8 ). By accelerating the subordination of Canadian production to the continental rationalization strategies of U.S.-based transnational firms, the FTA contributed to a major shakeout. Within a year of the FTA, 14 of 37 firms in the industry were lost (Industry Canada 1999a) and, by the mid 1990s, the industry had become so concentrated that three foreign-owned firms, Camco, Inglis and Frigidaire, accounted for three quarters of Canada's major appliance production (Industry Canada 1999c).

Job losses in this rationalization process have been massive. While some of these losses are cyclical, and technological displacement is another factor, continentalization of the industry is the major explanation. Disproportionate job loss has been borne by unionized workers. While much of the electrical and electronics sector has suffered unemployment, it is the most heavily unionized subsectors, especially the major appliance sector, which has the highest union density among the subsectors, that has been the prime target (CAW 1995: 5). Overall employment in the major appliance industry in Canada has thus declined from 13,800 in 1980 to

5. These tariffs applied to those countries with most favoured nation status (Industry Canada 1999c). 
7,600 in 1990 and, further, to 5,900 in 1997 (Statistics Canada, Catalogue 31-23). Altogether, and disaggregating for production workers only, Canada's major appliance industry has faced an average job loss of $3.6 \%$ a year from 1990-1998 (Industry Canada 2000: chap. 3). Any likelihood of net new jobs is low (Industry Canada 1999d).

As emphasized, weak external labour markets are a disciplinary stick that increases employee dependency. For some workers, this stick is being supplemented by a carrot: the polarization of internal labour markets. There is evidence that firm restructuring in the major appliance sector entails the development of a core of higher paid, more skilled workers and a periphery of cheaper, part-time and short-term flexible workers. According to senior union leaders, there has been a trend in the 1990s toward lower cost, part-time work in unionized plants. There has also been growing pressure to pay new hires lower wages and to extend probationary periods before new workers are entitled to full wages and benefits. In effect, reports a national union leader, "you're getting a two-tier wage system. And that helps to explain why even though the union has been negotiating wage increases, the average wage hasn't grown much at all." Tendencies to twotier internal labour markets also reflect a combination of shortages in the supply of core workers with specialized skills, on the one hand, and a surplus of less skilled peripheral workers, on the other (Industry Canada 1999c).

In this context, it is not only the peripheral workers whose employment is perceived as vulnerable. The employment security of many core workers is also fragile, given the decline in stable, full-time, unionized jobs. With less hiring into better-paid unionized jobs, and with contractual seniority provisions regarding layoffs, core unionized workforces tend to have older age profiles. With fewer "good jobs" available to these older workers in external labour markets, there is growing pressure on workers to protect their jobs by helping management to make their workplaces more competitive. A veteran national union leader explained:

What's happening now is you've got a[n older] workforce in many of our plants. [With] 15 to 20 years seniority, you can stay in the plant. [...] So as a result of that, those workers are saying, "when you look at my age," they're saying, "where else can I get a job under today's environment?" So that puts the pressure on them.

It is this combination of job insecurity and restructuring at the level of the industry that provides the context for understanding the rise of microcorporatist tendencies in the workplace, as the following case study demonstrates. 


\section{MICROCORPORATISM IN A MAJOR APPLIANCE PLANT}

Camco (Canadian Appliance Manufacturing Company), majority owned by General Electric Appliances (GEA) in the U.S., is the last big producer of major appliances in Canada. The firm has two plants, one in Hamilton, Ontario, the other in Montreal, Quebec. The Hamilton workers make ranges and refrigerators and are members of the Canadian Auto Workers; those in Montreal make automatic dryers and dishwashers and belong to the Canadian Energy and Paper Workers union.

Camco began restructuring in the 1980s. ${ }^{6}$ However, rationalization accelerated quickly under the continentalizing framework of the FTA and the competitive vulnerability it created. At the beginning of the $1990 \mathrm{~s}$ Camco produced entirely for the Canadian market; by the end of the 1990s, over half its production was for export (Camco 2000b). According to Camco, its declining domestic sales are due to its competitors selling below cost (dumping) (Camco 2000d). Camco's future has come to rest increasingly on its export orientation, which depends mainly on agreements to supply GEA and its affiliates, collectively Camco's largest customer. These agreements are essentially a function of the firm's ability to "leverage [its] highly flexible manufacturing capabilities" for niche production (Camco 1999: 4). Because this diversified producer competes with large foreign plants enjoying long, cost-efficient, production runs, its future revolves around its ability to produce high quality, niche appliances for high end markets.

As a key to its competitiveness, Camco lauds the "spirit of partnership" it enjoys with its employees, and argues that the active cooperation of union leaders and workers has been critical to its survival (Camco 1999: $3)$. This partnership is a major departure from what union leaders call the "horrendous" and "just terrible" labour relations at the plant in the 1980s, years in which the workers were widely known for their militancy during three long, bitter strikes. The new cooperative labour relations have been forged in the context of high levels of job insecurity during the recession of the early 1990s and the jobless recovery that followed. At the Hamilton plant itself, production jobs peaked in the mid 1980s, falling from about 1300 to about 700 jobs during the early and mid 1990s. Even though employment under Camco's new strategy has recently grown to over 1000 production jobs (of which about a quarter are in a second tier of limited term jobs), a deep sense of insecurity remains, helping to sustain Camco's cooperative labour relations system.

6. As part of a rationalization strategy in the 1980 s, Camco closed two plants and sold a third. 
Camco's new labour relations have developed separately at each plant. Because the Hamilton and Montreal plants are organized by different unions, produce different products and are sourced by different suppliers, the structural barriers to creating a common industrial relations framework are formidable. There is little communication between the unions in the two plants, and the absence of solidarity links between them has been another factor conditioning the development of microcorporatist tendencies.

These tendencies are integral to Camco's use of Japanese "lean production" principles. Impressed by Japanese productivity, Camco began to study Japanese production in the 1980s (Laver 1991a), and sent employees to "lean" factories in Japan, Europe and North America "to find out how to improve their productivity" (Laver 1991b). The turning point came in the early 1990s when Camco made the assignment of new refrigerator production to Hamilton contingent on worker and union agreement to implement Japanese cellular manufacturing principles.

The union's initial response was not favourable. The Canadian Auto Workers (CAW) had made opposition to lean production a major theme of its extensive educational programs for local leaders. ${ }^{7}$ According to a national union leader, the CAW's position was that it would not "buy into this total concept, of work cells, and team concept, and all the rest. No, we're not. You want to put the product here, fine, we'll support it and the workers in the shop will work with you, but we're not buying into your bloody team concept." Others responded differently. Chastened by job losses that had already taken place in the major appliance industry, including Camco, throughout the 1980s, and that had accelerated since the signing of the FTA, many saw Camco's flexible production strategy as a basis for potential job protection, particularly for workers with more seniority. A majority felt they had little choice but to accept the restructuring plan even while trying to minimize the damage the changes threatened.

As part of the agreement, the union and management set up joint training programs to introduce workers to the new labour process. In its course on "lean manufacturing" (which ran parallel to Camco's on "problem solving"), the union warned that lean production not only meant work intensification and the elimination of non-value-added work, but also, and more fundamentally, increased management control over workers and their

7. The CAW's orientation to lean production may help to explain why a more extensive range of such innovations were implemented at CAMCO's plant in Montreal where workers are represented by a union that is more sanguine about many of these innovations. Other factors, including Quebec's more corporatist industrial relations system and differences in the plant's products and production systems, are also likely explanatory variables. 
union. ${ }^{8}$ Under the circumstances, such warnings were in large measure prophetic but also inadequate.

In addition to cooperating out of job fear, many were influenced by two positive pressures. One was the example provided by Camco's Montreal plant. In return for participating in Japanese-based team production, quality circles, and training in problem-solving (Adams 1990), the Montreal workers had benefited from a $\$ 30$ million investment in a "state of the art" production system. Using Japanese production concepts, Camco introduced computer-controlled production, simplified product design, merged job classifications, and a kanban (demand-pull) system to reduce inventories. Camco also rewarded the Montreal workers with sole product mandates and thus additional job security (Laver 1991a: 29).

The provincial government ${ }^{9}$ provided the second positive inducement to cooperate with Camco's restructuring strategy. According to a union leader, management told the government that, due to the plant's conflictridden labour-management relations, Camco intended to close the Hamilton plant. As a result, the government pressured the union and management to save the plant. Led by government conciliators, Camco held a three-day labour-management "session" off site so that both sides could discuss what they felt was wrong in the plant and in their relationship. The session helped to clarify the roles of management and the union and both sides "ended up with a better understanding of what each other's jobs were about," a local leader reported.

\section{MICROCORPORATIST TENDENCIES}

The resulting agreement was the beginning of a more microcorporatist labour relations system. Subsequently, management and the union negotiated the elimination of almost three quarters of the job classifications, and gave supervisors more discretion to shift workers from job to job and to

8. In its education, the union distinguished between "working in groups" and "team concept." Whereas team work reduces skill levels, intensifies work, further standardizes and controls labour, and continually reduces production costs, "the union may or may not support some form of working in groups in a given workplace: it depends on a number of factors." The union's "framework for a response" included: (1) oppose lean production and work to change it through negotiations; (2) challenge the ideology of partnership and competitiveness through education programs for union members; (3) educate members about the logic of lean production; and (4) "respond to new structures and practices that management is setting up in the workplace." In effect, the union education argued, "we simply can't stand aside and just "let it happen," on the other hand, we can't just "buy in" (Presentation Notes, "Re: Lean Manufacturing" 21 October 1996).

9. At this time the social democratic New Democratic Party governed Ontario. 
change job content. Amalgamation of job classifications has been part of what management calls a "total cultural change." For example, whereas previously the quality of production was checked at the end of the assembly process, "now our operators do that at every step of the process," a Camco manager reported (Laver 1991a: 29) ${ }^{10}$ In conjunction with the introduction of computer-controlled conveyor technology and the kanban system to remove non-value-added production time, managers gave workers more responsibility and training related to reading production scheduling and using computers.

The new cooperative labour relations have been critical to these labour process changes. Camco focused first on the local union leadership. One reason for the earlier more adversarial labour relations was that plant floor representatives had enough time to write up grievances but lacked time for informal negotiations with supervisors. Recognizing that the local union was crucial to implementing its agenda, Camco agreed to create more full-time union representatives, including a full-time chair, three chief stewards, a benefit representative, four health and safety representatives and a women's advocacy representative. This expansion of the union's role allowed Camco to reduce what had previously been a large labour relations department.

A local union leader reports that the union's expanded labour relations role has made it more "visible" to the members. The local union has been settling far more conflicts over benefits, overtime, harassment, modified work for injured workers, and other issues. Moreover, it is doing so before they become formal grievances. Grievances are now a small fraction of what they were and most arbitrations have been eliminated. According to another local leader: "Today it's a whole different system where we can actually sit down and hash out agreements." Camco has "a better understanding of the union and their function, the need for both parties to be able to work together," he believes. "You've got to be flexible."

However, informal grievance resolution was not the most significant result of the changed relation between Camco and local union leaders. Thanks to the new representation structure, union stewards now also have time to participate in labour-management committees dealing with restructuring issues, such as the layout of production and the introduction of new products. The local president and the union's negotiating committee meet regularly with senior managers and technical personnel on a Steering Committee to discuss ongoing issues related to new products, production problems and labour relations. Below this are other committees that Camco

10. Similarly, in CAMCO's Montreal plant almost $90 \%$ of the inspection jobs were eliminated. 
creates in response to changing production problems and then dissolves when the problems have been addressed. Camco selects some of the committee members and the union selects others. A local leader reports that these subcommittees are set up to find "ways to cut costs on certain products so we can keep them in this country" since "under [the] Free Trade [Agreement] we're under threat all the time."

With more access to union leaders, Camco is able to target them with more information about managerial concerns and goals. Every weekday, local leaders attend plant production meetings where they "listen to all the problems," a national union leader explains. Local leaders also meet with management monthly to receive a "full financial account of where the plant is at." He adds that national union education programs help local leaders to gain the confidence and expertise needed to participate in these meetings. Several times a year, local leaders also attend meetings of Camco's Board of Directors where management provides reports on sales and losses, production schedules and forecasts, and corporate finances. Although much of the detail in the information given to union leaders is confidential, they are allowed to report upcoming layoffs to the members and provide them with impressions of Camco's competitive situation. According to a local leader, Camco gives the union, and thus the members, "a better understanding of the business" by being "more upfront with the union about how the business is operated." Another local leader says that as a result of this new relationship both union and management are taking "more of an honest approach" because now the union is "more involved in the operations of the business." Camco has "a better understanding of our needs and we have a better understanding of their needs."

Camco's new relation to the union has influenced the union's relation to its members. The time union leaders spend with managers is time they are not spending with their members. The new representation structures are also linked to new privileges that divide union leaders from their members. In addition to more time away from production jobs, union leaders now have offices of their own. Moreover, partly because many of the new representatives need special expertise to do their jobs, many are appointed by the union leadership rather than elected by the members. This too sets up barriers between the local union and members.

Workers themselves have been the other major focus of these changes in labour relations. In meetings with workers, managers emphasize foreign competition and stress that plant survival depends on their commitment to improved productivity and quality. At "Rendez vous" meetings, managers provide workers with detailed information about the major appliance market and Camco's competitive position. At departmental and group meetings, they supply workers with data on reject levels, scrap rates, absenteeism, 
quality, and production statistics, and urge them to improve. In addition to these regular communications, executives discuss competitive conditions and other issues with selected workers. Reinforcing these communications, friendly managers have given out small gifts, such as T-shirts and coffee mugs, to all production workers for achieving quality benchmarks and other productivity goals. For their participation in setting up teams or working on production layout and other restructuring issues, individual workers have received recognition (e.g., restaurant meals), time away from production jobs to discuss restructuring and other issues, and lucrative rewards (e.g., access to more overtime) that are outside the collective agreement.

As in the case of union leaders, Camco has selected workers for direct participation in a range of labour-management structures. Joint health and safety training, and training for stewards and supervisors related to modified work for injured workers, are key areas of cooperation that reduce labour-management conflict and provide benefits to workers. The new relationship has also included joint visits to plants in the U.S. and Canada to find out how Camco's productivity could be improved, joint committees to bring in new products, and joint committees where workers meet with managers and engineers to solve problems posed by new production processes. In another committee established with government aid, managers selected workers to participate in labour-management teams working on such areas as labour process design, technological change, and training and communications during the design and implementation stages of new production processes. ${ }^{11}$ Workers participated in regular "problem-solving" and "brainstorming" with supervisors and design and production engineers, and analysed the entire production process looking for ways to cut production costs by, among other things, removing labour and increasing production.

Some results of these cooperative relations have been significant. In one case, the union persuaded managers that the Hamilton plant could produce a product more cost effectively than it was being produced by an outside contractor. These contributions from workers and union leaders have improved the plant's productivity considerably, according to this local leader. Especially important has been the workers' role in reducing inventory costs by producing on a "just-in-time" basis (Laver 1991a: 28).

The "partnership" in these new labour relations is clearly not between equals. All the joint committees report to the Steering Committee, and Camco "always gets the final say," a local union leader explains. "It's their business," he adds. Productivity improvements notwithstanding,

11. According to a national union leader, this collaborative process was inspired by the union's experience with a similar project at a GM-Suzuki plant in Ontario. 
management shifted some of the plant's production to a non-union plant in the U.S. South. Camco cut about a fifth of the plant's workforce during the first half of the 1990s. Meanwhile, another major appliance maker in Canada shut down plants, including a plant where workers and unions cooperated with the introduction of similar flexible production systems (Sobel and Meurer 1994: 167). Yet, both despite and because of continuing job losses, and despite the inequality of the relation, the labour-management cooperation has deepened.

\section{FLEXIBILITY CONCESSIONS}

In the mid 1990s, as a prerequisite for major new investments, Camco demanded further flexibility concessions in the areas of worker mobility, work schedules, job descriptions, overtime, vacation scheduling, and work assignments (CAW 1998: 149-160). Despite previous flexibility concessions, the workforce was down to about half its peak 1980s level. Many were sceptical of the new demands. Camco assured the union leaders that the additional concessions would lead to new investments in the plant and new products. To sell the concessions, Camco flew local leaders to other plants to see how advanced flexible production systems operated. After the leaders returned, the negotiating committee recommended support for the "flexibility enhancing understandings," warning the members "to accept this or we lose the plant," a local leader recalled. A majority of the members accepted the concessions, many of them voting "out of fear of losing their jobs," he says. Another local leader reports that national union leaders instructed local leaders to do what was necessary to keep the plant open.

In calling for these new concessions, Camco argued that the union's explicit support for mandatory training, employee involvement and "quality commitment" was absolutely "essential to the longevity and security" of the plant (CAW 1998: 157). In a formal letter of agreement, the union assented:

It is the responsibility of every employee to produce a product in accordance with quality standards to meet customer expectations in order to ensure the ongoing viability of the Hamilton Production Operation. To this end, employees are responsible for actively supporting the implementation of new products and processes and the improvement of existing products and processes (CAW 1998: 156-157).

Management then put the union's commitment into every job description by adding that each worker's responsibilities "shall be performed consistent with meeting all customer requirements, quality standards, health, safety, environment and housekeeping objectives, and with building global competitiveness through continuous improvement" (CAW 1998: 159). The 
broader job descriptions required workers to sweep, tidy individual work stations, maintain orderly parts storage, recycle and dispose of waste and material, maintain quality control, perform minor machine maintenance and repair, and participate in "quality initiatives" (CAW 1998: 159-160).

Camco used the agreement to initiate a training program around GE's corporate-Wide Six Sigma quality program, which is designed to reduce defects through statistical monitoring. Camco gave selected workers Six Sigma training. Camco also gave all the workers a course in "problemsolving" that focused on ways to cut "waste" in production. At the same time, the union delivered training in computer literacy, and workers have frequently been required to monitor scrap, repair and other data. Quality surveillance functions have been shifted from supervisors to workers. Because production defects are systematically quantified, and the source easily identified by Six Sigma techniques, workers' ability to resist management control through workplace direct action (e.g., work to rule, sabotage) has been undermined. For its part, Camco claims the Six Sigma Program has created a "cultural shift" in the plant (Camco 1999: 9).

In these and other training programs, managers have the discretion to decide how well each worker succeeds. Moreover, training requirements may supercede seniority in the allocation of jobs (CAW 1998:157). Within parameters, managers also select those trained to operate and maintain new computer-controlled equipment. Workers compete for these training opportunities.

\section{FLEXIBILITY, WORKFORCE STRATIFICATION AND COOPERATION}

In addition to the job fears stemming from weak external labour markets and Camco's competitive vulnerability, the other major factor conditioning the new cooperative labour relations has been management's creation of a two-tiered and more individualized employment relation. As part of the concessions package Camco demanded in return for new plant investments in the mid 1990s, management created a second tier of student workers. The main rationale was that Camco needed a section of its workforce that could be hired and laid off quickly in response to the often high seasonal and cyclical volatility of demand for its products. ${ }^{12} \mathrm{~A}$ secondary rationale was that this would allow first-tier workers to take their vacations in the summer, as most preferred. Along with the other concessions, this division

12. An estimated $70 \%$ to $80 \%$ of demand in the Canadian market is for replacement appliances. These costly purchases are highly sensitive to short-term changes in interest rates, unemployment levels, and overall consumer confidence (Industry Canada 1999d). 
in the bargaining unit was formally ratified by the local union. It was agreed that second-tier workers could comprise up to a third of the workforce and would be hired on a 'just-in-time' basis for up to six months during times of high product demand. These workers are explicitly restricted to assemblyline jobs and lower employment grade levels. Although they pay union dues, they have no seniority rights, are paid about $80 \%$ of the wages firsttier workers receive for the same work and, except for a small life insurance policy, they have no fringe benefits (CAW 1998: 150). A national union leader estimates that the wage and benefit package for a tier two worker is more than $40 \%$ cheaper than that for a comparable tier one worker. Camco is "stealing from those kids," says a local leader, but adds that this was necessary "to secure that investment," according to the national union.

By privileging long-term, core workers in relation to this tier of temporary workers, Camco has divided the bargaining unit into first and second class members, while strengthening the bonds between management and core workers. Furthermore, because many student workers are relatives of managers and other salaried personnel (others are related to production workers), and are members of the bargaining unit, the second tier helps to reduce the differences between union and non-union identities.

Closer cooperation between management and core workers has also been encouraged by the way Camco's restructuring has been used to distribute individualized privileges. In particular, after participating in joint committees, some workers have been assigned better jobs, and others have gone on to other committees where their respite from production jobs has been continued, and where they have developed, as a local leader put it, a "sense of belonging." Others have benefited from differential access to the various training programs that the union and management have developed. This has allowed some to acquire new skills that have led to better jobs.

Partly because of the emphasis on eliminating "waste" in production, job restructuring has also stimulated individualistic orientations among workers. Jobs have been "tightened up" so there is less "idle time," a local leader reports. Some non-assembly line jobs have been contracted out, and there has been no overall increase in non-assembly line jobs, which can provide workers with more control over the pace of their work, reports another local leader. As a result, there are "less and less places you can put an injured worker." Not only injured workers, but older workers, who make up an increasing proportion of the plant workforce and often need lighter jobs, are finding themselves in increasing competition for preferred jobs.

Consistent with this increasing individuation of opportunities and increased competition for better jobs, workers and union leaders report a greater sense of individualism among the younger and better-educated 
workers Camco has been hiring. These hiring characteristics are consistent with the introduction of more complex technologies and more flexible jobs. Local union leaders report that these workers tend to take the gains the union has made for granted. "My generation went on strike [a local leader explains, and] it's difficult to impart to people [who were not part of those struggles] what you did to get there. The company propaganda machine is very, very efficient at bombarding younger workers with messages that union struggles are not a big factor in helping them make gains. After a while, younger workers buy that kind of propaganda. It's a brainwashing deal." They are also likely to feel they do not need union representation because, he reports, they often "know their rights better [and are] more outspoken." This rights orientation is increasingly directed against the union as well as against management. "There was a time when you represented your people [he reflects]. Now, while you're doing it, you've got to protect yourself against your own people. They can take you to the Human Rights, the Labour Board. [These younger workers' orientation is] more me, me, me, and the hell with them, what's in it for me? That type of attitude. Some even tell the company about things other people are doing so they can better themselves."

It is highly unlikely that the militant unionists who built the local and who repeatedly took on management in long strikes until the 1990s would have foreseen that, a mere decade later, they would be part of Camco's new cooperative labour relations. For all the changes that have taken place in labour relations, in products and in production technologies, most jobs in the plant are still highly taylorized and repetitive. Wages and benefits have improved somewhat in the 1990s, but not substantially. Management still makes most of the decisions, including the key investment decisions. Much has not changed in these years. What does seem to have changed, however, is the sense of identity that many workers have in relation to each other and in relation to management. The workforce is more fragmented and most workers and their local union are more aligned with management's competitiveness goals and with the restructuring strategies Camco has designed to achieve them.

\section{A Culture of Insecurity}

The main explanation for this new alignment is what one Camco worker calls a "culture of insecurity" in the plant. He noted an "overwhelming sense of relief" among his fellow workers when the most recent round of collective bargaining concluded with a new contract. He says that most workers in the plant, even those with a lot of seniority, see their job security in "three year segments" - the duration of each collective agreement. They are also keenly aware that their job security may last no longer than 
the market popularity of the plant's last product. Their priority is "maintaining the jobs." Camco's restructuring strategy, including the negotiated concessions and the various cooperative labour relations arrangements that are part of the restructuring, are seen to be the best way to keep jobs in the plant. In contrast to their opposition to Camco's restructuring strategy in the early 1990s, workers and the union now use it "to lobby the company to invest in new products," a local leader observes. They argue that because the plant has an experienced workforce, "a niche ability to go from one model to the next," and a capacity to "build to order" within three days, it has big advantages over low-wage, high-volume competitors.

A few years ago the union underlined the plant's labour flexibility in an appeal to the Board of Directors to make new investments. According to a union leader, this appeal "impressed the Americans and the Board of Directors," as did the union's cooperation with management's flexibility goals, particularly the job consolidations. In 1998, General Electric (Camco's major shareholder) gave the Hamilton plant an exclusive North American mandate to produce a luxury refrigerator. After the refrigerator was assigned, workers continued to make efficiency suggestions to the managers because they "wanted the jobs to last," a local leader explains, adding that it has been this ability to impress General Electric's Board of Directors that has also led to the assignment of subsequent new products to the plant as well. The refrigerator, together with recovery of U.S. consumer demand during the late 1990s, has resulted in substantial new hiring.

Worker identification with Camco's productivity goals has been further strengthened by the way that Camco used the new cooperative mechanisms and symbols to implement production of the new refrigerator. Workers took part in decisions about reconfiguring the labour process and in planning pre-production pilot runs. They also took part in aspects of marketing strategy. Further reinforcing this identification, Camco enlisted workers to field test the new refrigerators in their homes, and had workers sign their names all over one of the new refrigerators, which now sits in the plant lobby.

Today Camco calls itself "one of the Canadian NAFTA success stories" (Pettapiece 1998). With several products, including North American mandates for three GE appliances, Camco is the only major appliance manufacturer left in Canada that builds a full line of major appliances. Yet continental restructuring of the appliance industry, and aggressive price competition from large, specialized, low-wage GE plants in the U.S. and Mexico, continue to threaten Camco's future. A local leader estimates that over half the jobs in the plant are competing with other plants where workers produce the same (non niche) mass production appliances. The combination of rewards (new products) and threats reinforces workers' identification 
with managerial competitiveness goals. The union continues to pressure Camco to set up joint labour-management committees to discuss the feasibility of new products. "We're continuously trying to lobby the company into investing more product into the plant," says the same local leader. "There's always a threat of losing a product and our position as a union has been to try to convince the company to invest in other types of products to replace the products we see we're going to lose."

For now, union and worker cooperation with management appears to have helped them achieve their overriding goal: during the last few years employment at the plant has increased, and despite ups and downs in demand for Camco's products, the core workforce has been protected from layoffs.

\section{MICROCORPORATISM AND THE FUTURE OF LABOUR POLITICS}

The current combination of weak labour markets, increasing competitive pressures and flexibility-centred corporate restructuring strategies is not unique to Camco. To the extent that this combination of conditions is conducive to the kinds of microcorporatist tendencies that have developed at Camco, it seems reasonable to hypothesize that the Canadian industrial relations system may become more heterogeneous. As well as a larger nonunion component, enterprise unionism may become a more prominent feature. Because this direction signifies a weaker and more fragmented labour movement, it would not be consistent with traditional forms of social democratic politics. Nor would this direction be consistent with the social unionism emerging in parts of the Canadian labour movement (Adkin 1998; Turk 1997).

The Canadian Auto Workers in particular identifies itself with a social unionism that is linked to progressive social movement and class politics both inside and beyond the workplace. At the Hamilton plant, the local has a Women's Committee, for example, that has been actively confronting violence against women and children. The local supports the National Action Committee on the Status of Women, Canada's feminist umbrella organization of women's organizations. It also supports the White Ribbon Campaign against male violence. The local has an active Environmental Committee whose focus goes beyond workplace pollution to key environmental issues in the community. The national union is at the forefront in its "zero-tolerance" policies against racial and sexual harassment, and has provided education against sexual and racial harassment for managers as well as local leaders and members at the Camco plant. This social unionism also includes solidarity with the struggles of other workers in Canada and internationally. As a Camco union leader emphasized, the local doesn't 
"merely send the money that eases our conscience. We actively take partleaflets, forums, publicity, whatever we can."

Yet, while some local leaders are active in this social unionist politics, most "rank and file" workers at Camco are not. For example, aside from local leaders, few members from the local took part in the 1997 Ontario "Days of Action," the largest demonstration in Hamilton's history, in which over 100,000 marched through the city to protest the Conservative provincial government's cuts to a variety of social programs. According to reports, many Camco workers were hostile to the demonstration while others were simply not interested. A local leader argues that the divide between Camco's workers and more marginalized workers, whether they are the poor or public sector workers, has been growing.

You see, you're not in the fight if you got a job. If you've got a job and you're taking home a steady pay cheque then you're not in the recession. You're okay and all these hardships apply to somebody other than you.[..] Years ago everybody was in the fight. Not everybody is in the fight now.

This weakness in social solidarity among the membership is compounded by the elitism of many of the union's political processes. The local has not responded to Camco's participatory initiatives by giving priority to the involvement of members in union functions. Instead, most participatory initiatives flow almost exclusively from management and labour-management structures. Asked what the union has been doing to make its processes more open and democratic, a local leader replied there have been no changes in the local union structures. "Participation may have increased slightly inasmuch as we [the local executive], from time to time send them out a mailing explaining our view and what's happening." It is this participatory deficit in the union that Camco has taken advantage of in its appeals to workers to join labour-management committees and production teams. The worker participation ethos that might have driven the development of a more vigorous social unionism seems to have been captured to varying degrees by management-oriented processes that substitute for a politics of progressive social change.

While certainly not conclusive, these observations are consistent with the logic of labour-management unitarism that lies at the heart of microcorporatism. From this perspective, labour politics, whether social democratic or social unionist, dissolves into a marketplace of competing corporations. Viewed as a 'natural' response to external market competition, labour-management relations take on a depoliticized guise. In this way, corporate survival and job security become locked together in a single unifying, transcendent goal. Under these conditions, workers and local unions may continue to use higher levels of union hierarchies for certain collective bargaining, educational and government lobbying functions. 
However, the focus of local unions shifts increasingly toward the firm, and local union functions increasingly mesh with and cross over into managerial functions.

This is one general direction in which the kind of microcorporatist tendencies that have been emerging at Camco may evolve. However, as the case study suggests, such developments are contingent on important pressures external to the firm. Moreover, microcorporatist tendencies are by their nature internally contradictory. At Camco, large peripheral external labour markets and labour-disciplining state social and economic policies have been identified as key preconditions. In this context, evidence from Camco suggests that workers' cooperation with microcorporatist processes is shaped by pragmatic calculations of self-interest. There has been no indication that the Camco workers have internalized management goals as ends in themselves.

Related to the disciplinary role of external labour markets is a second condition that seems to be necessary to maintain the microcorporatist trajectory at Camco: the employer needs to offer sufficient employment and income security to maintain this pragmatic worker loyalty. Ironically, the competitive vulnerability (a problem of survival) that seems to be an underlying condition of microcorporatist restructuring also makes its continuation hostage to the same competitive vulnerability.

These microcorporatist tendencies are self contradictory in other fundamental ways as well. In particular, the stability of microcorporatism depends on workers not taking advantage of the more interdependent nature of their relation to more flexible labour processes. Just-in-time production systems and exclusive product mandates provide workers with more sources of potential power. By abandoning multi-sourcing to reduce costs and gain greater control over suppliers and the quality of supply, employers forgo the ability to whipsaw workers. It also becomes more difficult for management to contain the effects of worker resistance in one workplace, especially where inventories are "lean" and where lost production cannot be replaced with stepped-up production elsewhere.

More broadly, these microcorporatist tendencies have important contradictory implications for management control. To the extent that workers acquire technical, social and planning skills through participatory restructuring processes, there is increased potential for worker autonomy from management control. Such worker autonomy in the labour process implies a potential for worker resistance to unravel the microcorporatist relationship from within. 


\section{BIBLIOGRAPHY}

ADAMS, George. 1990. Worker Participation in Corporate Decision-Making: Canada's Future? Kingston, Ont.: IRC Press.

ADKIN, Laurie. 1998. Politics of Sustainable Development. Montreal: Black Rose.

BABSON, Steve. 1995. "Whose Team? Lean Production in Mazda USA." Lean Work: Empowerment and Exploitation in the Global Auto Industry. S. Babson, ed. Detroit: Wayne State University Press.

Betcherman, Gordon. 1999. "Workplace Change in Canada: The Broad Context." Contract and Commitment: Employment Relations in the New Economy. A. Verma and R. Chaykowski, eds. Kingston, Ont.: IRC Press.

Betcherman, Gordon and Graham Lowe. 1997. The Future of Work in Canada. Ottawa: Canadian Policy Research Networks.

BRANDES, Stuart. 1976. American Welfare Capitalism. Chicago: University of Chicago Press.

Burke, Mike and John ShIELds. 1999. The Job-Poor Recovery. Toronto: Ryerson Polytechnic University.

CAMCo. 1999. Annual Report for 1998. Mississauga, Ontario: Camco.

CAмсо. 2000a. Annual Information Form 1999. Mississauga: Camco.

CAMCO. 2000b. First Quarter Report for 2000. Mississauga: Camco, 9 May.

CAMCO. 2000c. Annual Report for 1999. Mississauga, Ontario: Camco.

CAmCO. 2000d. News Release. Hamilton, Ontario: Camco, August 2.

CANadian Auto Workers (CAW). 1995. Economic Overview of Canada's Electrical and Electronics Industries. Toronto: CAW.

Canadian Auto Workers (CAW). 1998. Collective Agreement Between Camco Inc. and the National Automobile, Aerospace, Transportation and General Workers Union of Canada (CAW-TCA) and its Local 504, 1998 to 2001. Hamilton, Ontario.

CRAYPO, Charles. 1994. "Meatpacking: Industry Restructuring and Union Decline." Collective Bargaining in the Private Sector. P. Voos, ed. Madison, Wisc.: Industrial Relations Research Association.

Derber, Milton. 1970. The American Idea of Industrial Democracy, 18651965. Urbana: University of Illinois Press.

Electrical and Electronic Sector Advisory Council. 1995. Ontario Electrical and Electronic Sector Strategy.

FAirbrother, Peter. 2000. Trade Unions at the Crossroads. New York: Mansell.

GrahAM, Laurie. 1993. "Inside a Japanese Transplant: A Critical Perspective." Work and Occupations, Vol. 20, No. 2.

IndUSTRY CANADA. 1999a. Business Information by Sector: Major Appliance Industry. Ottawa: Industry Canada, Nov. 1 (http://strategis.ic.gc.ca/SSG/ mh0308e.ht).

Industry CANADA. 1999b. Business Information by Sector: Major Appliance Industry: Apparent Canadian Market. Ottawa: Industry Canada, October 29. 
Industry CANADA. 1999c. Business Information by Sector: Profile of the Canadian Major Household Appliance Industry. Ottawa: Industry Canada, December 9.

Industry CAnada. 1999d. Profile of the Canadian Major Household Appliance Industry. Ottawa: Industry Canada (strategic.ic.gc.ca/SSG/ mh03098e.ht).

Industry CANADA. 2000. Canadian Industry Statistics: Major Appliance Industry. Ottawa: Industry Canada, May 5 (http://strategic.ic.gc.ca/SSG/ io33218c.ht).

JaCKSON, Andrew. 1996. The Future of Jobs: A Labour Perspective. Ottawa: Canadian Labour Congress.

JACOBY, Sanford. 1997. Modern Manors: Welfare Capitalism Since the New Deal. Princeton, N.J.: Princeton University Press.

JACOBY, Sanford and Anil Verma. 1992. "Enterprise Unions in the U.S." Industrial Relations, Vol. 3, No. 1, 137-158.

Jenson, Jane. 1990. "Representations in Crisis: The Roots of Canada's Permeable Fordism." Canadian Journal of Political Science, Vol. 23, No. 4.

Kenney, Martin and Richard FloridA. 1993. Beyond Mass Production: The Japanese System and Its Transfer to the U.S. New York: Oxford University Press.

LAver, Ross. 1991a. "Scrapping the Assembly Line: Camco Adopts a New Mind Set." Maclean's, 12 August.

LAVER, Ross. 1991b. "Refreshing Confidence.” Maclean's, 12 August.

LEE, Joohee. 1998. "Micro-Corporatism in South Korea." Economic and Industrial Democracy, Vol. 19, 443-474.

Magun, Sunder. 1998. Restructuring in Canadian Industries: A Micro Analysis. Ottawa: Industry Canada, Working Paper 23, June.

MCBRIDE, Stephen. 1992. Not Working. Toronto: University of Toronto Press. Moody, Kim. 1997. Workers in a Lean World. New York: Verso.

PAlmer, Bryan. 1994. Capitalism Comes to the Back Country. Toronto: Between the Lines.

Pettapiece, Mike. 1998. "Camco Redesigning Plant for Bottom-mount Products." Hamilton Spectator, 11 May.

PICOT, Garnet and Andrew HeISZ. 2000. Performance of the 1990s Canadian Labour Market. Research Paper Series 148. Ottawa: Statistics Canada.

Purcell, Theodore. 1960. Blue Collar Man: Patterns of Dual Allegiance in Industry. Cambridge, Mass.: Harvard University Press.

RineHART, James, Christopher HuXley and David RoBERTSON. 1997. Just another Car Factory? Lean Production and its Discontents. Ithaca, N.Y.: ILR Press.

Ross, Arthur. 1958. "Do We Have a New Industrial Feudalism?" American Economic Review, December, 903-920.

ScHATZ, Ronald. 1983. The Electrical Workers: A History of Labor at General Electric and Westinghouse, 1923-60. Urbana, Ill.: University of Illinois Press. 
Sobel, David and Susan Meurer. 1994. Working at Inglis: The Life and Death of a Canadian Factory. Toronto: James Lorimer.

Turk, Jim. 1997. "Days of Action." Open for Business, Closed to People. Diana Ralph et al., eds. Halifax: Fernwood.

Verma, Anil and Richard Chaykowski. 1999. "Business Strategies and Employment Relations." Contract and Commitment: Employment Relations in the New Economy. A. Verma and R. Chaykowski, eds. Kingston, Ont.: IRC Press.

Wells, Don. 1995a. "The Impact of the Postwar Compromise on Canadian Unionism." Labour/Le Travail, Vol. 36, 147-173.

Wells, Don. 1995b. “Origins of Canada's Wagner Model of Industrial Relations." Canadian Journal of Sociology, Vol. 20, No. 2, 193-225.

Wells, Don. 1996. "New Dimensions for Labour in a Post-Fordist World." North American Auto Unions in Crisis. E. Yanarella and W. Green, eds. Albany: State University of New York Press, 191-207.

Wells, Don. 1997a. "When Push Comes to Shove: Competitiveness, Job Insecurity and Labour-Management Cooperation in Canada." Economic and Industrial Democracy, Vol. 18, No. 2, 167-200.

Wells, Don. 1997b. "Why Canada Needs an Active Jobs Policy." Policy Options, Vol. 18, No. 3, 35-39.

Whyte, William F. 1957. The Organization Man. New York: Simon and Schuster.

Whyte, William and Kathleen Whyte. 1988. Making Mondragon: Growth and Dynamics of the Worker Cooperative Complex. $2^{\text {nd }}$ ed. Ithaca, N.Y.: ILR Press.

WillmotT, H. 1993. "Strength is Ignorance, Slavery is Freedom: Managing Culture in Modern Organizations." Journal of Management Studies, Vol. 30, No. 4, 515-552.

\section{RÉSUMÉ}

\section{Marchés du travail, spécialisation flexible et nouveau micro- corporatisme : le cas de l'industrie des appareils ménagers au Canada}

Dans le contexte particulier des organisations syndiquées, les changements apportés au processus de production et associés à la haute performance ainsi qu'aux systèmes de gestion participatifs ont le potentiel de créer des relations industrielles microcorporatistes apparentées à celles qui étaient en vigueur au début du $20^{\mathrm{e}}$ siècle au Canada, aux États-Unis et ailleurs. Ce microcorporatisme se manifeste notamment dans le syndicalisme japonais d'entreprise. Dans la mesure où ce potentiel est 
réalisé, ces formes de microcorporatisme pourtant en marge des systèmes de relations industrielles canadiens dans le passé, deviennent beaucoup plus centrales. Les changements de structures du marché du travail contribuent particulièrement à changer le système de relations industrielles. En effet, la reconfiguration des marchés interne et externe du travail autour de formes contingentes de travail augmente la dépendance des travailleurs pour des employeurs et des lieux de travail particuliers. Cette dépendance est de plus conditionnée par l'accroissement de la compétitivité inter et intraentreprise. Au Canada, particulièrement dans le secteur manufacturier, ces formes de compétitivité se sont accrues suite à l'entrée en vigueur l'Accord de libre-échange entre le Canada et les États-Unis (ALE) et de l'Accord de libre-échange nord-américain (ALENA). Face à de nouvelles pressions concurrentielles et de nouvelles technologies de production, plusieurs dirigeants d'entreprises ont saisi l'occasion de promouvoir ces nouvelles tendances microcorporatistes. Par exemple, dans les organisations qui introduisent de nouvelles technologies de production et qui poursuivent des objectifs de qualité, de flexibilité et de productivité, des stratégies de développement et de maintien du noyau de main-d'œuvre qui coopère davantage dans le processus de restructuration des lieux de travail sont mises en ouvre.

Ces liens entre les marchés du travail restratifiés, l'augmentation des pressions concurrentielles et les nouveaux processus de production, d'une part, et les nouvelles tendances microcorporatistes d'autre part, sont illustrés dans une étude de cas d'une usine de production d'appareils électroménagers qui a dû faire face à une rationalisation importante dans les dix dernières années. Cette rationalisation s'inscrit dans le cadre d'une restructuration continentale de l'industrie des appareils électroménagers au cours de laquelle des pertes d'emplois massives ont eu lieu ainsi que la disparition de la plupart des grandes entreprises de cette industrie au Canada. L'étude de cas suggère que les tendances microcorporatistes ne viennent pas de la construction d'une hégémonie profonde des valeurs managériales, ni du leadership syndical ou du noyau de main-d'œuvre. Elles semblent davantage refléter les adaptations pragmatiques des travailleurs à leur vulnérabilité croissante au chômage et au sous-emploi causée par les nouvelles réalités compétitives.

Finalement, il faut aborder la question de l'impact potentiel des tendances microcorporatistes sur le système des relations industrielles et sur l'avenir politique du mouvement ouvrier. En fait, ces tendances ont des implications contradictoires et contingentes. Elles impliquent tout d'abord la mise en place d'un syndicalisme local plus fragmenté intériorisant davantage la logique de compétitivité du marché au profit de l'érosion du syndicalisme en tant que mouvement social et des politiques de travail 
social-démocrates. Puisque ces tendances vers le microcorporatisme sont contingentes à la fois des conditions externes et intérieurement contradictoires, le mouvement ouvrier et le système de relations industrielles peuvent prendre une toute autre direction. En effet, ils peuvent se tourner vers les nouvelles formes de résistance des travailleurs, en particulier celles qui se concentrent sur un meilleur contrôle ouvrier du processus de production. 